Article

\title{
Floristic Composition and Litter Deposition in a Degraded Area and in Reforestation with Eucalyptus
}

\author{
Cláudio Francisco Brogni 1, Heitor Amadeu Prezzi 1, Gustavo Eduardo Pereira 2, Abelino Anacleto de Souza Junior \\ 1, Anderson Fernando de Souza ${ }^{1, *}$
}

\author{
${ }^{1}$ Centro de Ciências Agroveterinárias, Universidade do Estado de Santa Catarina, Lages, SC, Brazil \\ ${ }^{2}$ Universidade Federal de Santa Catarina, Curitibanos, SC, Brazil. \\ *Correspondence: anderson.sji@hotmail.com
}

\begin{abstract}
The present study aimed to verify the floristic composition in two distinct areas: reforestation with Eucalyptus and degraded area subjected to fire. Plots of $0.5 \mathrm{~m} \times 0.5 \mathrm{~m}$ were demarcated, distributed in transect in the two analyzed areas, were carried out. The analyzed aspects were the following: plant species variability, fresh mass, dry mass and litter. The results showed that the cultivation with eucalyptus was the one with the highest amount of plant species, reaching the number of 17 species, while in the degraded area 11 different species were found. In terms of fresh and dry mass, there was no observed difference between areas. In relation to litter, the cultivation with eucalyptus had the highest weight. It is concluded that the cultivation with eucalyptus showed the highest number of plant species and amount of litter; as for the fresh and dry mass, there were an equivalence in the results of the two areas.
\end{abstract}

Keywords: Flora; conservation; forest; burned.

How to cite this paper: Brogni, C. F., Prezzi, H. A., Pereira, G. E., Souza Junior, A. A., \& Souza, A. F. (2021). Floristic Composition and Litter Deposition in a Degraded Area and in Reforestation with Eucalyptus. Research Journal of Ecology and Environmental Sciences, 1(1), 52-56. Retrieved from https://www.scipublications.com/journal/index.php/rjees/article/view/88

Received: July 6, 2021

Accepted: August 13, 2021

Published: August 14, 2021

Copyright: (c) 2021 by the authors. Submitted for possible open access publication under the terms and conditions of the Creative Commons Attribution (CC BY) license (http://creativecommons.org/licenses /by/4.0/).

\section{Introduction}

The biodiversity of plant species is very important, with environmental impacts, affecting ecosystem services and ecological processes [1-3]. Regarding environmental functions, the impacts are direct, as all living beings participate in some way in the food chain, thus causing degradation or even removal of plant species by their habitat, which can lead to ecological imbalances $[1,4]$.

Among the main threats to biodiversity in a location is the degradation caused by fires, as in addition to affecting the fauna, low-lying vegetation and shrubs can be destroyed, depending on the intensity [5]. Thus, the affected ecosystem needs time to regeneration and may not reach the diversity that previously existed in the place $[1,5]$.

Another threat to diversity is the cultivation of species of economic interest because, in these areas, the vegetation is completely removed and its growth controlled so as not to interfere with the development of the culture of interest [6]. In this sense, the cultivation of eucalyptus has great importance in Brazil and in the world, and this forest species is the most cultivated in Brazil with approximately 7 million hectares and moving around 2 billion dollars in 2019 [6]. Its purpose is to be used in the civil industry and in the manufacture of cellulose as a raw material in paper production [6].

In view of this, this study aimed to compare the quantity and mass of plant and litter species in a reforestation of eucalyptus and a fragment of Atlantic forest degraded by fire.

\section{Materials and Methods}

The study was conducted between 2008 and 2009 in the city of Camboriú, Santa Catarina state in southern Brazil. Two areas were selected with different management, an 
area with a reforestation of approximately 0.5 hectares of Eucalyptus grandis with approximately three years old, and a fragment of the Atlantic forest biome with approximately one hectare burned one year before the assessments. In these areas, transects were delimited, where five parcels with dimensions of $0.5 \times 0.5$ meters equidistant were analyzed.

Then, the aerial part of all plant species existing in each plot was collected, except for the eucalyptus plants, and the fresh mass was determined in situ, with an analytical balance. Afterward, the samples were sent to the laboratory to count the amount of plant species present in each plot of each area.

The same material was then dried in a forced air circulation oven at $64^{\circ} \mathrm{C}$ for $72 \mathrm{~h}$ until they reached a constant weight, to determine the dry mass. Finally, all the litter present on the soil of the plots was collected and the fresh weight was determined. All values were transformed into $\mathrm{Mg} \mathrm{ha}^{-1}$.

The data obtained presented normality, by the Shapiro-Wilk test, and homoscedasticity, by the Bartlet test, and were compared by the $\mathrm{T}$ test with $5 \%$ probability of error. Data from each area were correlated using the Pearson correlation test. Statistical analysis and graphic production were performed using Sigmaplot 14.0 $0^{\mathrm{TM}}$.

\section{Results and Discussion}

Eucalyptus reforestation had a greater number of species when compared to the fragment of degraded Atlantic forest (Figure 1-C). In an already consolidated eucalyptus reforestation, such as the area collected in this study, there is a greater entry of sunlight between the treetops, favoring the development of a greater number of species in addition to a longer period for the species to establish themselves, three years against one year of the degraded area. In the degraded area, a higher number of pioneer species were observed (data not shown), these are the first plant species that colonize the areas under regeneration $[5,7]$.

Associated with the greater number of plant species found in the reforestation, a greater fresh mass was also observed, although there was no statistical difference (Figure 1-A). This was also observed in relation to the amount of dry mass (Figure 1-B). It is noteworthy that the eucalyptus trees that were within the plots were not measured, due to the difficulty of obtaining this measurement due to their size. Even with a longer time for species establishment under reforestation, the degraded area presented a fresh mass equal to that of reforestation, probably due to the rapid growth of pioneer species [8,9] present at this stage of regeneration. This type of plant species has great adaptability to different types of environment [8], so they quickly cover the soil and provide a favorable environment for tree species to develop and ecological succession occurs [8].

Concerning the litter deposition on the soil, we observed higher values in eucalyptus reforestation (figure 1-D). This fact is due to the greater number of secondary species in this area. Secondary vegetation includes shrub and tree species $[8,10,11]$ that end up contributing more to litter deposition than pioneer species [8,12].

With the degradation promoted in the area, the plants ended up debilitating and after approximately one year this area was in a regeneration stage, which even with the rapid growth of pioneer vegetation, little amount of litter is produced [13]. The pioneer species are mostly grasses, which have a tender stem and easy decomposition, compared to secondary vegetation species, which have woody stems, with a higher carbon: nitrogen ratio in their tissue. In addition to the fact that the burning ended up charring all the litter accumulated in this area. 

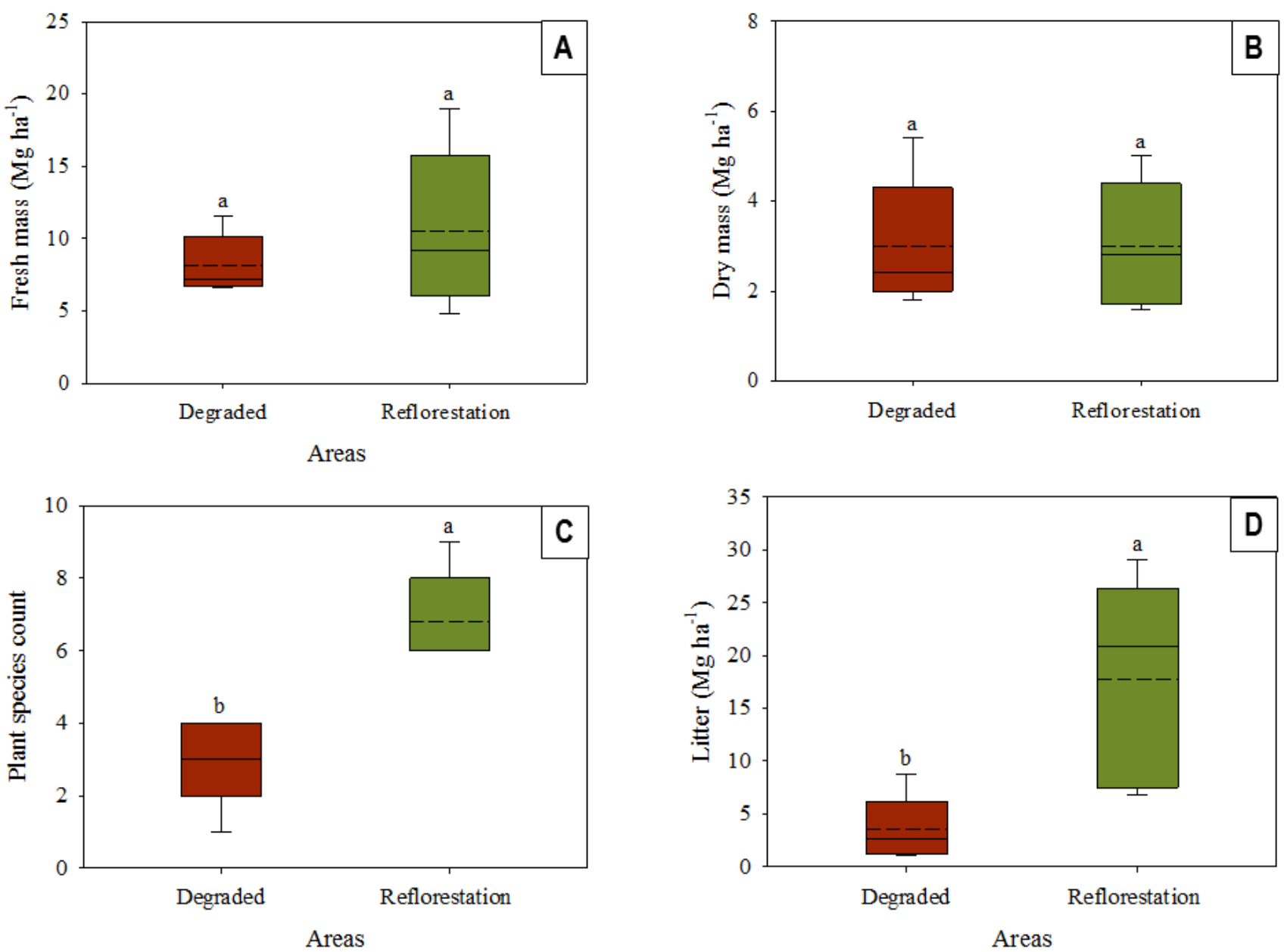

Figure 1. Fresh mass, dry mass, count of collected plant species and litter in a degraded area and eucalyptus reforestation.

The number of species observed in the degraded area showed a significant negative correlation with fresh and dry mass of vegetation and did not correlate with litter (Table 1). This is because the greater diversity of plants leads to greater competition between them in relation to water, soil nutrients and sunlight, in addition to the shading that can occur between species. Litter was not correlated with any variable, because in this short period of time, in terms of forest, the vegetation was not able to accumulate biomass [14].

In table 2, we observe that none of the analyzed variables showed a significant correlation with each other. This is because the main species that contributes to the accumulation of litter in this area was not analyzed, the eucalyptus plants [15].

Table 1. Correlations between the variables analyzed in the samples collected in the degraded area.

\begin{tabular}{lcccc}
\hline \multicolumn{1}{c}{ Variable } & Plant species count & Fresh matter & Dry matter & Litter \\
\hline Plant species count & 1 & $-0.96^{* * *}$ & $-0.88^{*}$ & $-0.88^{\mathrm{ns}}$ \\
Fresh matter & 1 & $0.97^{* * *}$ & $0.81^{\mathrm{ns}}$ \\
Dry matter & & & 1 & $0.81^{\mathrm{ns}}$ \\
Litter & & & 1 \\
\hline$* * *$ Significant at $0.1^{\%}$ probability of error * ${ }^{*}$ significant at $5 \%$ probability of error; ns not significant
\end{tabular}


Table 2. Correlations between the variables analyzed in the samples collected in the eucalyptus reforestation area.

\begin{tabular}{lcccc}
\hline \multicolumn{1}{c}{ Variable } & Plant species count & Fresh matter & Dry matter & Litter \\
\hline Plant species count & 1 & $0.08^{\mathrm{ns}}$ & $0.18^{\mathrm{ns}}$ & $-0.58^{\mathrm{ns}}$ \\
Fresh matter & 1 & $-0.32^{\mathrm{ns}}$ & $0.27^{\mathrm{ns}}$ \\
Dry matter & & & 1 & $0.81^{\mathrm{ns}}$ \\
Litter & & & 1 \\
\hline
\end{tabular}

*** Significant at $0.1 \%$ probability of error; ${ }^{*}$ significant at $5 \%$ probability of error; ns not significant.

\section{Conclusions}

Despite the degradation caused in the Atlantic Forest fragment, the vegetation shows good development, with fewer plant species than the eucalyptus reforestation area, but the same fresh and dry mass in both areas. The degraded area showed less litter deposition than the eucalyptus reforestation.

Author Contributions: Conceptualization, CFB; methodology, CFB, HAP and GEP; formal analysis and data curation, CFB, AASJ and AFS; writing-original draft preparation, CFB, AASJ and AFS; writing-review and editing, AASJ and AFS. All authors have read and agreed to the published version of the manuscript.

Funding: The authors would like to thank the Conselho Nacional de Desenvolvimento Científico e Tecnológico (CNPq) and Coordenação de Aperfeiçoamento de Pessoal de Nível Superior (CAPES, Finance Code 001) for the support in this study.

Conflicts of Interest: The authors declare no conflict of interest.

\section{References}

[1] Alho, C.J.R. The Value of Biodiversity. Braz. J. Biol. 2008, 68, 1115-1118, doi:10.1590/S1519-69842008000500018.

[2] Fromm, O. Ecological Structure and Functions of Biodiversity as Elements of Its Total Economic Value. Environ. Resour. Econ. 2000, 16, 303-328, doi:10.1023/A:1008359022814.

[3] Schmid, B.; Hector, A. The Value of Biodiversity Experiments. Basic Appl. Ecol. 2004, 5, 535-542, doi:10.1016/j.baae.2004.07.001.

[4] Edwards, P.J.; Abivardi, C. The Value of Biodiversity: Where Ecology and Economy Blend. Biol. Conserv. 1998, 83, 239-246, doi:10.1016/S0006-3207(97)00141-9.

[5] Melo, A.C.G. de; Durigan, G. Impacto do fogo e dinâmica da regeneração da comunidade vegetal em borda de Floresta Estacional Semidecidual (Gália, SP, Brasil). Braz. J. Bot. 2010, 33, 37-50, doi:10.1590/S0100-84042010000100005.

[6] IBA Relatório Anual 2020; Indústria Brasileira de Árvores: São Paulo, 2020; p. 120;.

[7] Yang, X.; Li, D.; McGrouther, K.; Long, W.; Li, Y.; Chen, Y.; Lv, X.; Niazi, N.K.; Song, Z.; Wang, H. Effect of Eucalyptus Forests on Understory Vegetation and Soil Quality. J. Soils Sediments 2017, 17, 2383-2389, doi:10.1007/s11368-016-1431-4.

[8] Miranda, J.C. Sucessão ecológica: Conceitos, modelos e perspectivas. SaBios-Rev. Saúde E Biol. 2009, 4.

[9] Tiebel, K.; Huth, F.; Wagner, S. Soil Seed Banks of Pioneer Tree Species in European Temperate Forests: A Review. IForest Biogeosciences For. 2018, 11, 48, doi:10.3832/ifor2400-011.

[10] Nunes, S.; Oliveira, L.; Siqueira, J.; Morton, D.C.; Souza, C.M. Unmasking Secondary Vegetation Dynamics in the Brazilian Amazon. Environ. Res. Lett. 2020, 15, 034057, doi:10.1088/1748-9326/ab76db.

[11] Alves, D.; Soares, J.V.; Amaral, S.; Mello, E.; Almeida, S.; Silva, O.F.D.; Silveira, A. Biomass of Primary and Secondary Vegetation in Rondônia, Western Brazilian Amazon. Glob. Change Biol. 1997, 3, 451-461, doi:10.1046/j.1365-2486.1997.00081.x.

[12] Sundarapandian, S.M.; Swamy, P.S. Litter Production and Leaf-Litter Decomposition of Selected Tree Species in Tropical Forests at Kodayar in the Western Ghats, India. For. Ecol. Manag. 1999, 123, 231-244, doi:10.1016/S0378-1127(99)00062-6.

[13] Villa, E.B.; Pereira, M.G.; Alonso, J.M.; Beutler, S.J.; Leles, P.S. dos S. Aporte de Serapilheira e Nutrientes em Área de Restauração Florestal com Diferentes Espaçamentos de Plantio. Floresta E Ambiente 2016, 23, 90-99, doi:10.1590/2179-8087.067513.

[14] Chambers, J.Q.; Higuchi, N.; Teixeira, L.M.; dos Santos, J.; Laurance, S.G.; Trumbore, S.E. Response of Tree Biomass and Wood Litter to Disturbance in a Central Amazon Forest. Oecologia 2004, 141, 596-611, doi:10.1007/s00442-004-1676-2.

[15] Giweta, M. Role of Litter Production and Its Decomposition, and Factors Affecting the Processes in a Tropical Forest Ecosystem: A Review. J. Ecol. Environ. 2020, 44, 11, doi:10.1186/s41610-020-0151-2. 